\title{
"ENTRE A CRUZ E A COROA, O TRONO E O ALTAR, A FÉ E O IMPÉRIO": O PADROADO REAL E A COLONIZAÇÃO BRASILEIRA A PARTIR DAS MINAS DO SERRO DO FRIO E VILA DO PRÍNCIPE, MINAS GERAIS, 1702-1721
}

Danilo Arnaldo Briskievicz ${ }^{1}$

Recebido em: 20/07/2020

Aprovado em: 10/09/2020

Resumo: Relacionamos a colonização das minas gerais, em especial do território das minas do Serro do Frio (1702) e sua Vila do Príncipe (1714), capital da Comarca do Serro do Frio (1720), com os ordenamentos da Coroa portuguesa, o Regimento dos Superintendentes (1702) e da Igreja católica, as Constituições Primeiras do Arcebispado da Bahia (1707). Analisamos documentos do cotidiano relativos aos dois regulamentos essenciais ao sistema do padroado real brasileiro do século XVIII, um deles o processo de habilitação sacerdotal. A metodologia de pesquisa bibliográfica permitiu investigação de documentos portugueses e brasileiros e sus análise tendo por base os fundamentos da microhistória ou análise microanalítica da história. $\mathrm{O}$ resultado se apresenta pari passu na narrativa dos fatos e culmina com a noção de que a colonização mineira se deveu aos regulamentos escritos da Igreja e da Coroa portuguesa introjetados na vida cotidiana das minas serranas.

Palavras-chave: Brasil Colônia; Colonização brasileira; Sistema do padroado; Comarca do Serro do Frio; Vila do Príncipe.

\section{"ENTRE CRUZ Y CORONA, TRONO Y ALTAR, FE E IMPERIO": EL ESTÁNDAR REAL Y LA COLONIZACIÓN BRASILEÑA DE LAS MINAS DE SERRO DO FRIO Y VILA DO PRÍNCIPE, MINAS GERAIS, 1702-1721}

Resumen: Relacionamos la colonización de Minas Gerais, especialmente el territorio de las minas de Serro do Frio (1702) y su Vila do Príncipe (1714), capital del distrito de Serro do Frio (1720), con la Corona portuguesa, el Regimiento de Superintendentes (1702) y la Iglesia Católica, las Primeras Constituciones del Arzobispado de Bahía (1707). Analizamos documentos cotidianos relacionados con las dos regulaciones esenciales para el sistema de mecenazgo real brasileño del siglo XVIII, uno de ellos el proceso de habilitación sacerdotal. La metodología de investigación bibliográfica permitió la investigación de documentos portugueses y brasileños y su análisis basado en los fundamentos de la microhistoria o el análisis microanalítico de la historia. El resultado se presenta pari passu en la narración de los hechos y culmina en la noción de que la colonización de Minas Gerais se debió a las regulaciones escritas de la Iglesia y la Corona portuguesa introducida en la vida cotidiana de las minas montañosas.

\footnotetext{
${ }^{1}$ Doutor em Educação. Professor de Filosofia e Sociologia do Instituto Federal de Minas Gerais - Campus Santa Luzia, Brasil. E-mail: doserro@ hotmail.com. ORCID: https://orcid.org/0000-0002-7652-1959.
} 
Palabras clave: Colonia Brasil; colonización brasileña; sistema de patronato; condado de Serro do Frio; Vila do Príncipe.

\title{
"BETWEEN CROSS AND CROWN, THRONE AND ALTAR, FAITH AND EMPIRE": THE REAL STANDARD AND BRAZILIAN COLONIZATION FROM THE MINES OF SERRO DO FRIO AND VILA DO PRÍNCIPE, MINAS GERAIS, 1702-1721
}

\begin{abstract}
We relate the colonization of Minas Gerais, especially the territory of the mines of Serro do Frio (1702) and its Vila do Príncipe (1714), capital of the Serro do Frio District (1720), with the Portuguese Crown, the Regiment of Superintendents (1702) and the Catholic Church, the First Constitutions of the Archbishopric of Bahia (1707). We analyzed everyday documents relating to the two regulations essential to the 18th century Brazilian royal patronage system, one of them the priestly habilitation process. The bibliographic research methodology allowed the investigation of Portuguese and Brazilian documents and their analysis based on the fundamentals of microhistory or microanalytical analysis of history. The result is presented pari passu in the narrative of the facts and culminates in the notion that the colonization of Minas Gerais was due to the written regulations of the Church and the Portuguese Crown introjected into the daily life of the mountainous mines.
\end{abstract}

Keywords: Colony Brazil; Brazilian colonization; Patronage system; Serro do Frio County; Vila do Príncipe.

\section{Introdução: de Roma às minas do Serro do Frio, a travessia pela linha do Equador}

O Concílio de Trento reformou a Igreja católica depois da reativação da vida urbana na Europa com suas novas dinâmicas sociais, políticas e econômicas. Um concílio para os novos tempos europeus. Assim, de 1545 a 1563 o $19^{\circ}$ Concílio da Igreja católica convocado pelo Papa Paulo III resolveu aproximar os padres dos fieis devotos (VILLALTA, 2007a, p. 19). Para tanto, foi necessário assegurar uma unidade em torno da profissão de fé católica e instituir uma renovada disciplina eclesiástica. Era uma reação institucional à reforma protestante iniciada por Martin Luther em 1517 com a publicação de suas 95 teses na igreja do castelo de Wittenberg.

Se considerarmos que a principal meta a longo prazo do Concílio de Trento - aproximar padres dos fieis devotos, reformar sua doutrina e reformar e moralizar o clero - foi declarada no séc. XVI, na Itália, no continente europeu, como explicar o processo de chegada de suas ordens ao território serrano? O longo processo pode ser justificado pela temporalidade: a distância entre o Brasil e a Europa e dentro do Brasil entre os territórios demarcados pela colonização portuguesa explica a lentidão das reformas. Assim, entre 1563 e 1713 passaram-se exatamente 150 anos. Um tempo longo. Uma reforma a longo prazo. Contudo, ela foi efetiva, não sem conflitos e resistências, do clero e do rebanho de fiéis devotos ou "massa de fiéis" (VAINFAS, 1997, p. 62). 
Quando analisamos a atuação dos padres no território serrano salta aos olhos a permanência de um discurso oficial pelas autoridades eclesiásticas constituídas. De fato, a forma de implantação do Concílio de Trento em terras brasileiras, mineiras e serranas foi marcado pela pedagogia moralizadora com muitos continuísmos barrocos - a incrível capacidade de cisão entre corpo e alma, entre pecado e salvação, entre a cidade dos homens e a cidade de Deus. Contudo, a regra básica foi a mesma da Idade Média: em caso de descumprimento, use-se a violência. Nas minas do Serro do Frio instituiu-se uma "pedagogia do medo [...] constituída pela intimidação sistemática das populações e que fazia da utilização de castigos, de encenações teatrais e de atos penitenciais, instrumentos de atemorização e, com isso, de educação dos fiéis" (VILLALTA, 2007a, p. 20). Mas não poderia haver uma pedagogia do medo sem os dispositivos de punição. Por isso, apesar da vigilância e da punição exemplar terem se tornado no séc. XVIII cada vez mais simbólica do que de fato real, factual, visível, ela criou os seus ícones. Por isso, os ícones do poder operaram na modernidade política segundo Foucault (2017, p. 33) como os dispositivos que disparavam em cada indivíduo o medo, por conta de uma ampliada “tecnopolítica da punição". É que para Foucault, a modernidade política institui através de mecanismos e dispositivos de vigilância e punição das populações a lógica de que o corpo age e se coloca no mundo por conta do adestramento disciplinado do pensamento. Controlar a alma tornou-se fundamental para controlar as populações.

Nas relações sociais baseadas na pedagogia do medo e no medo da punição exemplar, os indivíduos tentavam se socializar em tentativas de acomodação a este sistema buscando suprimir o desprazer, o desconforto, o incômodo, a fim de controlar subjetivamente o perigo das ameaças que são internalizadas cotidianamente. É que o coletivo/social dominava o indivíduo e o modelava, simbolicamente. De fato, o medo criou o assujeitamento ou o adestramento dos indivíduos pois eles passaram a vivenciar e a reproduzir modos específicos de existência criados como mecanismos de defesa para a sua autopreservação relacionados ao mundo do trabalho, às relações amorosas, afetivas e sexuais e às suas relações com o sagrado e a vida após a morte. Os mecanismos de defesa individuais fizeram com que a alma aprisionasse o corpo (FOUCAULT, 2017, p. 33) por conta dos dispositivos da violência.

A luta pelo poder nas terras mineiras - entre autoridades eclesiásticas, portuguesas, paulistas, baianas, entre bandeirantes e aventureiros, entre as pequenas inquisições e os fiéis devotos - mostra-nos um cenário em que a religiosidade católica buscou sua afirmação em terras serranas. Parece ter conseguido. O projeto de longo prazo do Concílio de Trento de aproximação da Igreja católica de seus fiéis através dos padres preparados intelectualmente e moralizados nos seus comportamentos, em outras palavras, letrados e polidos, deu resultado 
nas minas gerais e nas minas do Serro do Frio. Por isso, sob a tutela dos padres, fossem eles encomendados ou colados, adjuntos ou capelães, surgiu uma das expressões mais vivas da relação de poder entre a Igreja e seus fiéis, as irmandades leigas. Por conta disso, apareceu, depois de 150 anos nas minas do Serro do Frio o que Villalta (2007a, p. 20-21) chamou de "sombra tridentina" representada pelo "incentivo à invocação e ao culto dos santos, elementos de suma importância para a constituição das irmandades".

Portanto, a moralização pedagógica serrana, seja pela pedagogia do medo ou pela pedagogia da punição, faces da mesma moeda, teve nos capítulos da história da atuação dos padres da Igreja católica o surgimento de intrincada rede de autoridades e (des)autorizações, acordos e desacordos, permissões e punições. Na porta estreita da pedagogia moralizadora eclesiástica colonial aparentemente a miscibilidade racial e os inúmeros casos de ilegitimidades constituíram-se formas de resistência da população. Para muita moral, muita contravenção. Para muita moralização, muita imoralidade. Para muita confissão, muita penitência. Para muito pecado, as pequenas inquisições. Este é um movimento tipicamente barroco, dualista, binômico, ou seja, uma luta entre o sagrado e profano, entre as sombras tridentinas e os regulamentos e ordenações dos arcebispados e das paróquias.

\section{Do Vale do Paraíba para as minas do Serro do Frio: a primeira ermida}

A primeira evocação de um santo nas minas do Serro do Frio foi dada a Santo Antônio. De fato, no Livro Primeiro da Fazenda Real (PINTO, 1902, p. 939-962) o escrivão da Fazenda Real Lourenço Carlos Mascarenhas de Araújo, anotou no dia seguinte ao descobrimento oficial, ou seja, em 15 de março de 1702, o nome das minas serranas como dedicadas a Santo Antônio do Bom Retiro do Serro do Frio, no arraial de seu ribeirão, "pousada do guarda-mor Soares, mandou este ao seu escrivão que nesse mesmo livro declarasse a sua muita pertinácia por descobrir novas minas, à sua custa, com diligências exatíssimas, deixando de assistir nas minas gerais do Rio das Velhas, donde se separou com seus escravos, abandonando cômodos mais fáceis [...] e aqui pousou" (PINTO, 1902, p. 939). Mas o nome parece não ter vingado entre os bandeirantes e o povo que começou a se reunir nas datas auríferas.

Foi o bandeirante Gabriel Ponce de Leon (c.1665-c.1746), um dos fundadores do arraial de Conceição do Mato Dentro, ocupante dos arraias de Tapera, Córregos e Morro do Pilar que revelou explicitamente a devoção paulista à Senhora da Conceição. No seu testamento, Manuel Ponce de Leon, registrado no livro 3, fl. 31v., de 1737, declarou haver levantado a antiga capela da Conceição no Mato Dentro, "morada de Nossa Senhora da Conceição, cuja imagem mandou 
vir de Itu em 1703" (COSTA, 1975, p. 31), doando também “um terreno no Vintém, para a ermida da Senhora Santana" (COSTA, 1975, p. 31). Isso aconteceu nos primeiros anos de ocupação do vasto território das minas do Serro do Frio. O fato de Ponce de Leon ter dedicado uma ermida para Nossa Senhora da Conceição e outra para Santana Mestra indicava sua devoção compartilhada com seus companheiros de descobrimentos e trabalhos nos leitos dos rios a procura das pintas de ouro. O trânsito da imagem de Nossa Senhora da Conceição entre Itu, em São Paulo e as minas do Serro do Frio em 1703 em direção ao Mato Dentro demonstra que a tradição portuguesa de evocação de sua padroeira já estava estabelecida em solo brasileiro. Era comum, aceita, compartilhada. Por isso, na pousada sabarense ou primeira rancharia da Vila do Príncipe, Santo Antônio perdeu sua patronagem dos descobertos para a padroeira portuguesa, Senhora da Conceição. Isso mostra uma lógica das primeiras capelas erguidas nesse território. Normalmente, as capelas tinham como padroeiro Jesus Cristo (Bom Jesus do Matozinhos, construída pela irmandade das Mercês e São Benedito) ou Nossa Senhora (Conceição construída pela irmandade do Santíssimo Sacramento e Purificação pela irmandade de São Francisco), ficando os santos de irmandades leigas com altares laterais. Exceção feita à capela de Santa Rita, especificamente capela de santo e as igrejas do Rosário e do Carmo dedicadas à Nossa Senhora. Havendo capela, haveriam ofícios divinos. E quem, então, coordenava esses ofícios? Os padres. Eles prestavam os serviços cobrando taxas em oitavas de ouro. A primeira referência aos padres nas minas do Serro do Frio dá conta que eles eram religiosos, ou seja, pertenciam às ordens ou congregações religiosas. Eles espalharam nomes de santos pelos ribeiros: "há menção de serem arrematadas datas no córrego da Conceição, até hoje com este nome; no córrego de São Bento, hoje ignorado, mas onde frei Columbano fez um batizado que foi registrado, na Matriz da Vila; constam os córregos do Iguapé, da Purificação, da Glória, hoje ignorados" (SILVA, 1928, p. 26-27, grifos do autor). O padre frei Columbano era beneditino, ou seja, religioso da Ordem de São Bento:

Aos oito dias do mês de outubro de mil setecentos e cinco anos quintou o padre frei Columbano de Santa Escolástica, monge do Patriarca São Bento cem oitavas de ouro de que pagou de quintos à fazenda de sua majestade, que Deus guarde, vinte que logo perante mim escrivão e o guarda-mor Antônio Soares Ferreira recebeu o tesoureiro José Borges Pinto e ficaram oitenta oitavas, que leva o dito padre frei Columbano em pó por não haver ainda fundição nestas minas de que fiz este termo que ele assinou e o dito tesoureiro e guarda-mor comigo escrivão e eu, Lourenço Carlos Mascarenhas de Araújo, o escrevi e assinei. Antônio Soares Ferreira, Lourenço Carlos Mascarenhas de Araújo, José Borges Pinto, frei Columbano de Santa Escolástica (PINTO, 1902, p. 949). 
Mas havia também outros freis, frades ou monges nas minas serranas. No dia 18 de março de 1706, Mécia Preta quintou 60 oitavas de ouro em nome do padre frei João Batista, monge do patriarca São Bento, ou seja, um monge beneditino. Mécia Preta também quintou no mesmo dia sua senhora Izabel Maria da Cruz, pagando pelas 120 oitavas de ouro, 24 que ficaram com a Fazenda Real. O trio - Mécia Preta, Izabel Maria da Cruz e o frei João Batista mantinha relações próximas. Talvez Izabel Maria fosse sua concubina, fato comum nesta época, aceito socialmente, inclusive. Talvez fosse sua concubina a escrava Mécia Preta, em busca de sua alforria. O fato é que tanto Izabel Maria quanto o frei João Batista dependiam dos serviços nas datas de ouro feitos pela escrava. Ela era reconhecida pelos oficiais da Fazenda Real como procuradora dos dois. Mécia Preta além de minerar o ouro, declarou-os e quintou-os, oficialmente.

Os freis, frades ou monges eram padres. Prestavam serviços na capela de Nossa Senhora da Conceição ou outras ermidas que pudessem haver no território das minas serranas. Sobre frei Columbano não sabemos de onde veio, nem para onde voltou de suas aventuras pelas datas de ouro serranas. Já o frei João Batista voltou para Pernambuco, de onde veio.

Em relação aos ofícios divinos prestados pelos freis, frades e monges pouco ou quase nada se sabe. Frei Columbano deixou registros de seus batismos nos livros da paróquia, segundo anotou dr. Dario. Frei João Batista não deixou nada registrado. Por sorte, haveriam tantos outros freis, frades e monges, como constam das reclamações feitas contra a presença deles nas minas gerais. Essas reclamações originaram-se, especialmente, de duas situações: por um lado, aos religiosos era proibido possuir terras, mas isto não os impedia de ir até as minas de ouro lavrar os ribeiros; por outro lado, eles eram acusados pela "relaxação dos costumes" (COELHO, 1994, p. 110), em especial por emitirem discursos contra a arrecadação dos quintos do ouro, em desobediência à autoridade portuguesa, além de estarem distantes de suas comunidades, onde deviam, de fato, praticar seus ofícios divinos. Em poucas palavras: os religiosos eram desobedientes civis e viviam em grande liberdade pelas minas de ouro, com apoio popular, como já indicado, sendo vistos como fundamentais para as devoções populares e a ministração dos sacramentos. Essa presença dos freis, frades e religiosos nas minas de ouro acabou por ser proibida através de várias ordenações das autoridades do governo português. Provavelmente, quando chegamos ao ano de 1710 já não havia mais religiosos nas minas do Serro do Frio por conta das sucessivas ordens para sua expulsão. A ausência dos freis, frades e monges impediu radicalmente que houvessem nas minas gerais do séc. XVIII ordens religiosas masculinas ou femininas. Sem congregações, ordens ou comunidades religiosas de freis ou freiras consagrados 
aos serviços pastorais, quem cobriu esse espaço foram as irmandades, confrarias e associações de leigos (BOSCHI, 2007a, p. 277).

Nos primeiros anos das minas do Serro do Frio havia grande interesse do Governo-geral da Bahia na pessoa de dom Rodrigo da Costa em ter maiores informações sobre o que se passava nesses territórios. O objetivo era, evidentemente, disciplinar os descobrimentos e garantir os rendimentos para a Superintendência das Minas, de acordo com o Regimento de 1702. Por isso, em carta datada de março de 1705 remetida ao guarda-mor das minas do Serro do Frio Antônio Soares Ferreira o governador-geral do Brasil afirmou:

[...] As minas que chamamos de São Paulo, são as gerais, e destas é que falo a Vossa Mercê sobre a distância daquele, a esse distrito, e toda a clareza mais, que Vossa Mercê me puder dar, neste particular a estimarei muito. A ordem em que Vossa Mercê me fala de Sua Majestade, sobre se expulsarem das minas, aquelas pessoas, que consta serem prejudiciais a elas, não veio a este Governo, porquanto se não acha na Secretaria deste Estado; porém entendo deve estar na do Governo do Rio de Janeiro, aonde mando pedir a cópia dela, e vindo, a remeterei a Vossa Mercê, pois é certo, não pode deixar de haver esta ordem, por ser muito útil, e necessária ao serviço do dito Senhor, e bem público; sem embargo de que para se dar a execução a separação dos membros podres que a República sustenta, não é necessário recorrer mais que à ordenação do Reino, que manda se exterminem, por evitar as perturbações, e desassossegos de que a sua inutilidade, serve à paz pública; e assim deve Vossa Mercê não consentir que os tais vão infecionar essa nova Povoação, porque se nela se tiver esta cautela, se poderá fazer, sem controvérsia o serviço de Deus, e de Sua Majestade, porque sem esta utilíssima consideração, virão sem dúvida esses Povos, a experimentar os grandes danos, que hoje sem remédio, choram os que têm povoado as minas gerais; o que desejo se não verifique nessas, que Vossa Mercê tem sido descobridor, em quem descubro não só o zelo do serviço de Sua Majestade, mas também o de Deus Nosso Senhor, que é o que mais convém, a todos os que nascemos com a felicidade de católicos. [...] Também me parece dizer a Vossa Mercê, me deve mandar uma lista de toda a gente que se acha no descobrimento dessas minas, assim eclesiásticos, como seculares, e escravos, com toda a clareza, e distinção, e em nenhum caso consinta Vossa Mercê, que nelas andem estrangeiros de nenhuma nação que sejam, nem os admita em nenhum caso, antes ponha todo o cuidado, em que não entrem nesses distritos, por ser esta prevenção, utilíssima ao serviço de Sua Majestade, e livrarmos por este modo, de se enriquecerem tanto os Reinos Estranhos, por ser justo, lucrem os nossos naturais, o que a indústria daqueles sabe adquirir [...] (BIBLIOTECA NACIONAL, Documentos Históricos, , v. XL, 1938p. 357-360).

$\mathrm{Na}$ carta acima registraram-se muitos aspectos importantes sobre os primeiros anos das minas do Serro do Frio. O primeiro, sem dúvida, é relativo às distâncias do território brasileiro. Das minas do Serro do Frio à cidade da Bahia, Salvador, eram pelos $1000 \mathrm{~km}$ a pé, com montaria ou não. Por isso, dom Rodrigo cita os perigos desse longo caminho: as traiçoeiras montanhas e o contato com as sociedades indígenas que não aceitavam estranhos em seus territórios, além da precariedade do velho caminho até as minas gerais, que ele considerava 
ainda território paulista (Minas Gerais tornou-se capitania autônoma, em 1720), com muitos descaminhos para o ouro, fato tão reconhecido pelas autoridades que toda denúncia seria bemvinda. Outro dado importante diz respeito à república, ou seja, ao sossego e paz pública nas minas do Serro do Frio, obrigação dos bandeirantes que não deviam aceitar controvérsia, podendo expulsar e exterminar os revoltosos. O governo da república - o sustento do povo pelo abastecimento de alimentos e serviços e pela garantia do sossego de todos com garantias de serviços religiosos - era fundamental para manter a lógica dos descobrimentos: em primeiro lugar, os rendimentos da Coroa portuguesa contendo os descaminhos do ouro, em segundo lugar, a garantia da ordem republicana.

A expulsão dos freis, frades e monges, ou seja, de todos os religiosos ou padres regulares das minas do Serro do Frio ocorreu de forma sistemática em constante combinação entre a autoridade do governo português no Brasil, o governador-geral e a autoridade episcopal da Diocese de São Sebastião do Rio de Janeiro, em especial, dom Francisco de São Jerônimo que a governou de 1701 até 1721 . Por trás dessa disputa pelo rebanho dos fieis devotos católicos estava também outra: a disputa entre os bispos do Arcebispado da Bahia e da Diocese do Rio de Janeiro, como veremos mais à frente. Interessou ao governo português desde o início que o rebanho das minas gerais pertencesse ao pastoreio do bispo do Rio de Janeiro, o que foi feito. $\mathrm{Na}$ Bahia as congregações religiosas dos padres regulares adquiriram com o tempo grande influência no cotidiano das paróquias com suas obras sociais e suas igrejas. Ao que tudo indica, nas minas gerais o desejo era que se evitasse o modelo baiano de atendimento aos fiéis devotos católicos. Dessa forma, diferentemente do que aconteceu com expulsão dos jesuítas ou inacianos da Companhia de Jesus do Brasil em 1759 através de um alvará, para que os freis, frades e monges e padres regulares abandonassem as minas gerais foram várias ordens e diligências. Eles acabaram por entender que não eram bem-vindos naquele território. Além do registro da carta acima do governador-geral ao guarda-mor das minas do Serro do Frio de 1705, outro documento de 09 de novembro de 1709, uma carta de dom João V ao governador da Capitania de São Paulo e Minas do Ouro Antônio de Albuquerque ordenou-o colaborar com o bispo do Rio de Janeiro e da Bahia aplicando despejo e efetuando prisões dos clérigos ociosos existentes na região mineradora. Ocioso queria dizer sem paróquia, ou seja, distante da observação e controle de um bispo.

Nas minas do Serro do Frio rapidamente erigiu-se a matriz da freguesia de Nossa Senhora da Conceição para disciplinar o trânsito dos padres regulares e substitui-los pelos do hábito de São Pedro, os padres seculares ou diocesanos. Isso se deu em 17 de novembro 1713 (MESQUITA; SEABRA, 2015, p. 31). Pouco tempo depois, em 05 de fevereiro de 1714, o 
primeiro padre encomendado recebeu sua provisão. O licenciado padre Antônio de Mendanha Souto Maior, cunhado de Lucas de Freitas de Azevedo, o bandeirante ou sertanista paulista, tornou-se o primeiro vigário da freguesia de Nossa Senhora da Conceição ficando nela até 24 de junho de 1719 (MESQUITA; SEABRA, 2015, p. 65).

\section{As Constituições Primeiras do Arcebispado da Bahia de 1707}

\section{A publicação das Constituições Primeiras do Arcebispado da Bahia estruturou a} reforma católica e sua contrarreforma no Brasil. Sua importância organizacional está no mesmo patamar do que foi a publicação do Regimento dos Superintendentes, Guarda-mores e Oficiais Deputados publicado em 1702 pelo governo para os descobrimentos de ouro e diamantes durante as primeiras décadas do séc. XVIII nas minas gerais e outras capitanias.

Dom Sebastião Monteiro da Vide (1643-1722) foi nomeado para o Arcebispado da Bahia, por dom Pedro II, no dia 08 de maio de 1701. Dedicou-se a regular o culto aos santos e a desenvolver a piedade devocional, bem como preocupou-se com a dignidade das construções diocesanas: "estamos diante de homem de Igreja que manifesta a sensibilidade religiosa de uma época em que o 'desencantamento' ainda não havia tocado a alma humana e a própria Igreja" (FEITLER, SALES, JANCSÓ, PUNTONI, 2010, p. 24) caracterizando-se como homem barroco $^{2}$ na forma de harmonizar "dois arquétipos do prelado tridentino: o ideal de pobreza, ou,

\footnotetext{
${ }^{2} \mathrm{O}$ jeito barroco serrano de ser derivou destas profundas conexões entre Portugal e Bahia, entre a vida cotidiana profana e os ofícios divinos e sagrados. Casimiro (2020, p. 4-5), explica, ampliando o contexto da escrita das constituições: "como a religião Católica era obrigatória, por ser a religião oficial do Estado, todos deveriam submeter-se às regras que eram impostas, sendo a desobediência passível de punição. O próprio clero era destinatário de enormes parágrafos sobre essas regras e sanções. Assim, os colonos procuravam participar dos ofícios religiosos e do exercício da fé cristã, assistindo à missa, pagando seus dízimos, confessando, rezando pelos seus mortos e prevenindo a salvação das suas almas, com legados para a celebração de missas post mortem. Buscavam, com tais atitudes, encontrar apoio e conforto espiritual, diante da instabilidade de suas vidas e ansiando pela salvação após as suas mortes. Por isso, uma das formas mais comuns de manifestação religiosa colonial foi a participação dos leigos em misericórdias, confrarias, ordens terceiras e associações religiosas mais informais. Instituições estas que proliferaram às centenas na colônia e que permitiam crer e vivenciar. E, na medida em que permitiam vivenciar, davam o exemplo, divulgando a fé. Para alguns, ser membro de uma ordem terceira ou irmandade significava, além da possibilidade de praticar a religião, ter acesso à nata da sociedade branca, ter status. Significava a obtenção de privilégios, graças e indulgências; significava, além do acesso aos bens celestiais, a facilidade aos bens materiais e o socorro nas vicissitudes [...]. Só que não era fácil pertencer a algumas ordens. $\mathrm{Na}$ Venerável Ordem Terceira de São Francisco, por exemplo, muitos eram os pedidos de filiação, mas poucos eram aceitos. Algumas dessas instituições eram constituídas apenas de pessoas socialmente bem situadas, como as Misericórdias, as ordens do Santíssimo Sacramento, de São Francisco e de Nossa Senhora do Carmo. Outras, como a de N.S. do Rosário dos Pretos, Santa Efigênia e São Benedito [...], irmanaram segmentos mais desassistidos da população que, daquela forma, se agruparam desenvolvendo modos de autopreservação e a ilusão de serem 'colegas' dos irmãos de outras ordens mais ricas. Afinal, deveriam pensar ingenuamente, saíam juntos nas mesmas procissões e o que diferia era apenas a precedência, com o direito das mais ricas de seguirem na frente. Como era de praxe, no que diz respeito à educação desse período, a Igreja tomou a si o papel principal, entretanto, ofereceu oportunidades desiguais, manifestou preconceitos, justificando-os, em nome do Evangelho".
} 
em todo caso, de humildade, dos homens de Igreja, e a dignidade e grandeza que seu cargo implicava" (FEITLER, SALES, JANCSÓ, PUNTONI, 2010, p. 24). Isso se mostrou na sua preocupação em manter vida simples, em edifício episcopal opulento. De fato, sua missão episcopal foi, em luta com os carmelitas e ouvidores, promover a centralização da sua autoridade e reformar os costumes locais, presentes "na implementação em força das normas tridentinas no arcebispado da Bahia e, até certo ponto em decorrência desta, uma exaltação da pessoa do arcebispo e de sua mitra" (FEITLER, SALES, JANCSÓ, PUNTONI, 2010, p. 32).

O espírito tridentino de reforma da Igreja católica e a constante necessidade de marcar sua presença na contrarreforma levou o arcebispo primaz do Brasil a convocar o Sínodo Diocesano de 1707 em que foram aprovadas as Constituições que já estavam escritas e passaram a valer para todas as dioceses sufragâneas. De fato, as Constituições modelaram o comportamento dos bispos e dos padres em praticamente todo o séc. XVIII. Trata-se de um instrumento jurídico-pastoral, "formado pelo conjunto de leis, decretos e disposições episcopais, e por fezes também de bulas e breves papais e leis régias, que regulavam a vida litúrgica, doutrinal e disciplinar de uma diocese, fundadas no direito canônico, na tradição da Igreja e em práticas consuetudinárias locais" (FEITLER, SALES, JANCSÓ, PUNTONI, 2010, p. 50-51).

São cinco livros: o primeiro explica a profissão de fé católica, a obrigação do ensino da doutrina cristã pelos párocos aos seus fiéis devotos, a obrigação da denúncia dos hereges e da adoração da virgem maria, de determinados santos e de relíquias, insistindo na autoridade dos padres e seu ofício de ministradores dos sete sacramentos e os modos e condições de sua administração. O segundo livro disserta sobre o sacrifício da missa e da obrigação de ouvi-la aos domingos e dias santos, do respeito dos dias de guarda e da realização de jejuns e abstinências, assim como da obrigação do pagamento das conhecenças - as somas pagas aos padres pelos fregueses da paróquia pelos sacramentos e missas, bem como a contribuição obrigatória do domingo de páscoa - e do dízimo eclesiástico. O terceiro livro trata dos ofícios divinos, das horas canônicas, das procissões, ladainhas e pregações, bem como descreve a doutrina cristã, centrada nas pessoas da Santíssima Trindade, insistindo na realidade brasileira colonial, ensinando como falar da doutrina aos escravos, a fim de serem catequizados. No quarto livro explicam-se as imunidades e isenções das pessoas eclesiásticas e do estatuto especial das igrejas, seus ornamentos e outros prédios sacros, descrevendo as formas corretas de fazer e cumprir os testamentos, sobre os enterros - Jacinta de Siqueira em seu testamento cumpriu fielmente as determinações desse capítulo em 1751 -, as sepulturas e as exéquias dos fiéis e sobre as confrarias. O quinto livro trata dos delitos sob a jurisdição episcopal, das penas 
e censuras aplicadas aos que neles incorressem e dos procedimentos básicos do tribunal eclesiástico, muito comuns nas visitas pastorais nas minas gerais setecentistas, as chamadas pequenas inquisições ${ }^{3}$.

As Constituições não criaram novas formas de devoção ou de culto popular, antes, disciplinaram as já praticadas e que deviam ser reguladas pelos bispos e padres reconhecidos por sua piedade e exemplos de vida cristã na colônia e em Portugal. Dessa forma, seu objetivo é homogeneizar os ensinamentos pastorais na colônia, tornando-se um instrumento de consulta e de regulação dos procedimentos eclesiásticos. Dessa forma, sua influência é definitiva para a formação da religiosidade popular das minas gerais, pois o que estiver autorizado em suas linhas será incentivado e tornado naturalizado. No caso da edificação da primeira matriz da freguesia de Nossa Senhora da Conceição nas minas do Serro do Frio seguiu-se à risca a recomendação Número 687, do Título XVII:

As igrejas se devem fundar e edificar em lugares e decentes e acomodados, pelo que mandamos que, havendo de edificar de novo alguma igreja paroquial em nosso arcebispado, se edifique em sítio alto e lugar decente, livre da umidade e desviado, quanto for possível, de lugares imundos e sórdidos, e de casas particulares e de outras paredes, em distâncias que possam andar as procissões ao redor delas, e que se faça em tal proporção que não somente seja capaz dos fregueses todos, mas ainda de mais gente de fora, quando concorrer ás festas, e se edifique em lugar povoado onde estiver o maior número de fregueses (VIDE, 2010, p. 393-394).

A igreja matriz das minas do Serro do Frio foi edificada, de fato, no alto, distante do cotidiano das primeiras lavras de ouro à beira dos ribeiros do Lucas e do Quatro Vinténs, bem como das atividades das lavadeiras de roupas na beiras desses mesmos córregos e de suas fontes que forneceram água potável para os moradores nas primeiras décadas da povoação. Da mesma forma, a teologia moral em vigor no séc. XVIII relativa às confrarias ou irmandades leigas foi disciplinada. No Número 869, Título LX, lê-se:

E posto que da devoção e piedade de nossos súditos podemos confiar que, sem esta nossa lembrança, a terão de instituírem em suas igrejas confrarias em que sirvam a Deus e honrem a seus santos. Nós contudo, para mais os animar, lhes rogamos e encomendamos muito que tratem desta devoção das confrarias e de servirem e venerarem nelas aos santos, principalmente a do Santíssimo Sacramento, e do nome de Jesus, à de Nossa Senhora e das almas do

\footnotetext{
${ }^{3}$ Para Santos (2013, p. 58), "as visitas pastorais conferiram especial impulso ao trabalho fiscalizador e coercitivo do tribunal eclesiástico no século XVIII. Recomendadas em Trento, elas coadunavam-se, àquela época, à detecção das formas de penitência e de livramentos mais temidos pelos leigos. Dom Sebastião Monteiro da Vide, arcebispo metropolitano da Bahia, responsável pela organização das Constituições Primeiras daquele Arcebispado, recomendava aos visitadores, vigários gerais, promotores e demais ministros eclesiásticos, muita consideração ao determinar qualquer tipo de castigo, seja pecuniário, espiritual ou corporal, examinando bem as circunstâncias, particularidades e o escândalo que resultasse do delito, e procurando o que se pudesse aliviar o réu, perdoar e comutar".
} 
purgatório, quanto for possível e a capacidade dos fregueses o permite, porque estas confrarias é bem as haja em toas as igrejas (VIDE, 2010, p. 452).

Os preceitos acima foram seguidos à risca nos primeiros anos das minas do Serro do Frio e implantadas radicalmente pelos párocos na freguesia de Nossa Senhora da Conceição. Por isso, a Irmandade do Santíssimo Sacramento tornou-se uma das primeiras a serem erigidas a fim de garantir o patrimônio para a manutenção da matriz, ao mesmo tempo que a de Nossa Senhora do Rosário, que nela funcionou durante muitos anos até a construção de sua capela própria. O santíssimo sacramento é a devoção à própria eucaristia - ato de consagração e conversão do pão/hóstia no corpo e sangue do Cristo prerrogativa dos sacerdotes, instituída pelo próprio Jesus Cristo e sua irmandade coligou a devoção ao sacramento e à sua imagem. Com o passar dos anos e o aumento da população e de devotos na povoação serrana, a irmandade do Santíssimo Sacramento tornou-se fundamental para a organização da semana santa, a mais importante festividade da Igreja católica, por culminar no domingo da páscoa, dia também em que os padres recolhiam as suas conhecenças anuais.

Enquanto o Regimento de 1702 ordenava e disciplinava os descobrimentos das minas, datas e lavras de ouro, as Constituições de 1707 ordenavam e disciplinavam a reforma católica e a contrarreforma nos contrafortes do Brasil colonial, nas minas gerais e nas minas do Serro do Frio. Nesse sentido, o cotidiano nas minas e o dia a dia da religiosidade popular ordenavamse pelas sagras letras. A necessidade de escrever regras, de determinar em regimentos o comportamento esperado de todos e de cada um, discriminando autoridades e autorizações marcou os primeiros anos das minas serranas. Se por um lado o regimento das minas dividiu o leito dos ribeiros em braças de terras que com o passar dos anos se tornaram os loteamentos urbanos da Vila do Príncipe, por outro, o regimento eclesiástico determinou a forma e o lugar da construção das igrejas e capelas, da posição correta dos cemitérios, a necessidade dos adros para as procissões, as primeiras irmandades para criar, fortalecer ou manter o patrimônio dos templos - as fábricas paroquiais, a atuação dos padres, a possibilidade das pequenas inquisições pelas visitas pastorais, a ministração dos ofícios divinos, missas e sacramentos, o catecismo dos escravos e a forma de sua conversão. Pode-se afirmar que o ouro - administrado pela Coroa portuguesa e a devoção cristã - administrada pela Igreja, seus bispos e padres, ou seja, a política da espada e da cruz, do regalismo e do catolicismo forjaram o jeito barroco serrano de ser. Isso tudo se deu por conta da instalação desde os primeiros dias, do sistema do padroado, perpetuado nas minas do Serro do Frio de 1702 até 1889.

O padroado era um sistema ou regime cuja origem remonta à Idade Média. Tudo girava em torno da troca de benefícios: a Igreja instituía um padroeiro de território determinado, para 
propagar a fé cristã e em troca este patrono recebia privilégios, como a coleta dos dízimos e a nomeação de religiosos para funções eclesiásticas. Isso em relação ao seu pressuposto medieval. Quando as minas do Serro do Frio foram descobertas em 1702, o padroado atuava como regime baseado no regalismo, ou seja, a Coroa portuguesa podia interferir nas questões religiosas da Igreja, como nomeação de bispos e padres, assim como a autorização para a criação de paróquias/freguesias, construção de templos, aprovação dos compromissos das irmandades, confrarias ou associações leigas. Era um toma-lá-dá-cá entre coroa e igreja. Segundo Boxer (2013, p. 87):

A aliança estreita e indissolúvel entre a cruz e a coroa, o trono e o altar, a fé e o império, era uma das principais preocupações comuns aos monarcas ibéricos, ministros e missionários em geral. [...] Durante séculos, a união da cruz e com a coroa foi exemplificada pela peculiar instituição [...] do padroado real da Igreja do ultramar exercido pelas coroas ibéricas: Padroado Real, em português, e patronato (ou Patronazgo) em espanhol. O Padroado Real Português pode ser vagamente definido como uma combinação de direitos, privilégios e deveres, concedidos pelo papado à Coroa portuguesa, como patrono das missões católicas e instituições eclesiásticas na África, Ásia e Brasil.

Havia, evidentemente, pontos de tensão e acertos historicamente sedimentados. No final das contas, em 1702 o estágio do padroado era aquele em que a Coroa portuguesa tinha mais poder e autoridade que a Igreja. Isso fica claro em relação às várias e sucessivas tentativas de expulsões dos religiosos ou padres regulares das minas, desafetos das autoridades portuguesas, por insubmissão e relaxação moral. De outra forma, os bispos tentavam se ajustar aos novos tempos, organizando o atendimento dos seus devotos por exigência da sua reforma e contrarreforma - as sombras tridentinas - ao mesmo tempo em que viam a possibilidade de ampliar o seu rebanho e garantir a arrecadação de seus rendimentos em tempos de opulência das minas de ouro.

O regime do padroado funcionou de modo interessante para a Coroa portuguesa. Os oficiais do governo nunca foram pessoas bem vistas nas minas, por conta das suas diligências e controle armado da população. Assim, era muito importante para o reino estabelecer novas hierarquias: os padres controlavam as consciências através do sacramento da confissão, obrigatório pelo menos uma vez ao ano na semana santa por ocasião da celebração da páscoa, mediando possíveis conflitos entre os interesses portugueses em nível local; ajustavam com autoridade o comportamento considerado adequado da população em suas paróquias/freguesias, instituições estas que sobre certo aspecto eram exatamente o limite do termo da vila com seus arraias e povoados, podendo afirmar que as cidades mineiras do séc. XVIII, muitas delas vilas do ouro e diamantes, cresceram em volta de uma igreja, capela ou 
matriz. Em uma palavra: os padres eram os olhos da Coroa portuguesa no território das minas gerais.

Essa parceria explica como se misturavam o pagamento dos rendimentos dos padres encomendados e colados. A paróquia ou freguesia tinha seu funcionamento regularizado quando elegia um padre para oficiar os sacramentos e rezar as missas. $\mathrm{O}$ padre encomendado como indica o nome, não era fixo, ficava na paróquia por tempo determinado, era um prestador de serviços provisório, à espera da resolução da diocese em provisionar um padre fixo, um vigário paroquial, o padre colado. A diferença entre um padre encomendado e um padre colado era o item mais problemático da negociação com as autoridades reais e diocesanas: os rendimentos anuais. No caso de um padre encomendado era facultado que em suas atividades cotidianas na ministração dos sacramentos e ofícios divinos fossem cobradas taxas pelos serviços, as conhecenças. Segundo Trindade (1928, p. 986), conhecença era o nome dado ao "dízimo pessoal com que cada fiel é obrigado a contribuir para a côngrua subsistência de seus pastores”. De 1702 até 1724, os fiéis devotos das minas do Serro do Frio e Vila do Príncipe pagaram as conhecenças. Era um gesto comum pagar pelos serviços divinos e sagrados. Um costume comum era que no dia da páscoa - a desobriga pascal - os fiéis contribuíssem com uma conhecença especial, a fim de colaborar para a manutenção do pároco encomendado. Por outro lado, um padre colado, vigário ou pároco, garantiria seu direito de receber cerca de $200 \$ 00$ anuais do governo português.

Villalta (2007b, p. 29) explica que "tratava-se, sobretudo, de uma profissão à qual a pessoa se dedicava como se fazia em relação às outras então existentes" uma vez que "o clérigo, ao tornar-se pároco e ocupar os demais cargos na hierarquia eclesiástica, ao receber côngrua (um salário anual) do governo, transformava-se num 'funcionário público', melhor dizendo, num 'oficial', um titular de um ofício do rei"; assim, "as côngruas e o ingresso numa carreira 'pública', em si, não eram os elementos que tornavam o estado de eclesiástico atraente" (VILLALTA (2007b, p. 30) pois “o regime de 'salários' dos clérigos (as denominadas côngruas) foi instituído em 1632, quando a Coroa passou a recolher os dízimos eclesiásticos e, em contrapartida, a remunerar os párocos e demais clérigos beneficiados" (VILLALTA (2007b, p. 30); ele conclui afirmando que "os reajustes das côngruas entre 1681 e 1752 jamais corresponderam às necessidades dos párocos" (VILLALTA (2007b, p. 30) e "para remediar a situação, generalizou-se no Brasil a prática de se cobrar taxas - as chamadas conhecenças - por ocasião da desobriga pascal (a confissão anual obrigatória por ocasião da Páscoa)" (VILLALTA (2007b, p. 30). 
Ademais, ser padre no século XVIII assim como toda e qualquer profissão, tinha seus benefícios e mazelas, ônus e bônus, alegrias e tristezas. Não se pode perder de vista, contudo, que se tratava de uma profissão para homens brancos e de bons costumes. Da chegada ao seminário para os estudos até o recebimento das primeiras ordens e posterior ordenação sacerdotal, havia um longo processo de avaliação do sangue, da vida e dos costumes (genere, vitæ et moribus) regulados pelo Regimento do Auditório Eclesiástico da Bahia, vigente desde 1704. A profissão sacerdotal exigia a mobilização de uma ampla rede de interesses, relações sociais entre famílias e párocos, entre bispos e futuros sacerdotes. Exigia-se negociação para conseguir os documentos, as declarações, as indicações, a realização das promessas de paróquias em freguesias lucrativas. Nesse teatro social das aparências, a atuação dos futuros sacerdotes era marcada pelo nascimento, posto que deles "exigia-se a posse de uma renda mínima, para que eles não vivessem em condições que conspurcassem a imagem do estado eclesiástico" (VILLALTA, 2007b, p. 37). Essa atuação levava em conta jamais aparentar pobreza de berço, mas certa opulência e riqueza. Ser pobre de berço tiraria nobreza, mostrar-se pobre e simples como virtude, acrescentava ainda mais prestígio social e reverência dos paroquianos. O berço era fundamental para que existisse um sacerdote na Igreja reformada e contrarreformista da primeira metade do séc. XVIII. Neste período, consolidou -se a noção de que ao sacerdote a natureza devia dotar desde o nascimento de qualidades reveladoras de sua vocação ao serviço divino nos templos. Assim, criou-se o costume de verificar o defeito de sangue, chamado mulatismo eclesiástico.

Villalta (2007b) analisou o caso dos três irmãos Albano de Souza Coelho, José Caetano Corte e Joaquim de Souza Lopes, que precisaram comprovar não ter defeito de sangue, passando pelos testes de mulatismo para serem ordenados. Segundo o historiador, eles "tinham uma avó parda, escrava do ouvidor-geral do Serro Frio, com o qual fora para a Bahia e de onde retornara forra" (VILLALTA, 2007b, p. 42). A avó era uma escrava do primeiro ouvidor da Comarca do Serro do Frio, que saiu de Sabará para assumi-la em 1720, permanecendo até 1727. Por este período, a sua escrava, avó dos habilitandos voltou da Bahia alforriada, provavelmente para morar na Vila do Príncipe. Ele prossegue a narrativa: “Albano e José foram dispensados de mulatismo 'em grau remoto', por Inácio Correia de Sá, 'atendendo a necessidade de sacerdotes"” (VILLALTA, 2007b, p. 42), sendo que "Joaquim também obteve dispensa de mulatismo, em 1768, sob a mesma alegação; esses habilitandos, além disso, não apresentaram certidões de batismo e casamento dos pais e avós, pelo o que foram ameaçados de ter suas ordens suspensas" (VILLALTA, 2007b, p. 42-43). Dessa forma, "talvez a complacência da justiça eclesiástica com tais habilitandos tivesse relação com seus laços de parentesco, pois 
tinham tios e primos de segundo grau na carreira eclesiástica; o avô materno deles, ademais, era Familiar do Santo Ofício" (VILLALTA, 2007b, p. 43). Por causa do hábito de exigir a comprovação da negativa de mulatismo "saiu contra os irmãos Lopes Oliveira processo que visava conseguir reverendas para que a ordenação de José de desse no Bispado do Rio de Janeiro, onde ele estava aguardando embarque para Coimbra, a fim de continuar seus estudos" (VILLALTA, 2007b, p. 43); conclui que "e certo que ao menos José Lopes conseguiu habilitarse, posto que à época da Inconfidência [1789] já pertencia aos quadros do clero" (VILLALTA, 2007b, p. 43).

A conferência oficial do sangue infecto não era praticado apenas no Brasil, antes veio importado de Portugal. Isso se confirma pela habilitação sacerdotal do português Pascoal da Cunha Pereira (1696-1761), aprovada em 1713.

O padre Pascoal era irmão do Capitão de Dragões Simão da Cunha Pereira (1700-1774) e do dom frei Brás da Cunha Pereira (1693-1780), ambos vindos para o Brasil. Trata-se de uma tradicional família portuguesa do final do séc. XVII e início do séc. XVIII, sendo os pais do habilitando José da Cunha e de Maria da Cunha, segundo o processo, naturais da freguesia de São Tiago de Infesta, concelho de Coura; pela parte paterna, neto de Francisco da Cunha, da freguesia de Santa Maria de Cunha, do lugar da Costa, e de Joanna Francisca, do lugar de Lis, freguesia de Infesta; pela parte materna, neto de João Fernandes da Cunha, do lugar da Costa, freguesia de Cunha, e de Anna Rodrigues, da freguesia de São Tiago de Infesta, todos no concelho de Coura (PEREIRA FILHO, 2009, fl. 3).

O processo de genere começava, como de costume, pelos motivos da habilitação, ou seja, a sua justificativa formal e quais eram os interessados na coleta e levantamento das informações. Nesse caso, o depósito formal do processo com as informações sobre sua ancestralidade cabia ao interessado em receber as ordens maiores para exercício pleno do sacerdócio. Dessa forma, anuncia-se a comissão comissionada para o encaminhamento do processo:

[...] Pedindo-me lhe mandasse fazer suas diligências de genere, para o que faria o depósito necessário, ao que, sendo por ele satisfeito / por meu despacho / na mão do Secretário que esta subscreveu, lhe mandei, com todo segredo, passar a presente, pela qual cometo ao dito Comissário; que sendo-lhe esta entregue, indo por mim assinada e selada com o selo desta corte, logo, com o dito Secretário, se suspeito ou impedido não for, e, sendo-o, com um Clérigo Notário Apostólico, ou Escrivão, que o dito Comissário elegerá, contanto que faça boa letra e legível, seja sem suspeita e cristão velho inteiro; ao qual dará o juramento dos santos evangelhos e, de suas mãos, o tomará também sob cargo; do qual, prometeram ambos, de bem e verdadeiramente fazerem deu ofício neste caso; de que tudo se fará termo de apresentação desta Comissão que será por ambos assinado (PEREIRA FILHO, 2009, fl. 5). 
O processo continua com a designação das autoridades legalmente constituídas e a nomeação do escrivão, elemento fundamental para a escrita de todas as informações, nesse caso, o padre Leonel de Caldas, vigário das freguesias de São Miguel de Barroca e de Santo André das Pias, do dito termo de Monção, dita Comarca e Arcebispado:

Inquirição de genere de Paschoal da Cunha, filho legítimo de José da Cunha e de sua mulher, Maria da Cunha, da freguesia de São Tiago de Infesta, concelho de Coura, Comarca de Valença. Ao primeiro dia do mês de Maio do ano de mil setecentos e treze anos, nesta freguesia de São Tiago de Infesta, concelho de Coura, comarca de Valença, deste arcebispado de Braga, aonde era vindo o Reverendo José Pereira de Souto Maior, Comissário do Santo Ofício e Reitor da freguesia de São Tiago de Pias, do termo de Monção, da dita comarca, do arcebispado, por Comissão do Muito Reverendo Padre Doutor Domingos Pinheiro Manuel, Provisor da Corte e arcebispado de Braga, para tirar inquirição de genere a Paschoal da Cunha, desta freguesia de Infesta, para cujo efeito ele, Reverendo Comissário, mandou chamar ele, Reverendo Comissário, a mim, o Padre Leonel de Caldas, vigário das freguesias de São Miguel de Barroca e de Santo André das Pias, do dito termo de Monção, dita Comarca e Arcebispado, para ser escrivão, desta Inquirição, para, digo, Inquirição e me deu juramento dos santos evangelhos, para que a escrevesse bem e fielmente na verdade e, debaixo do juramento que da sua mão recebi, prometi escrever a verdade, como também ele Reverendo Comissário, debaixo do seu juramento prometeu inquirir as testemunhas desta Inquirição, sem dolo, afeição, nem malícia, de que, de todo, ele, Reverendo Comissário, me mandou fazer este termo, que ambos assinamos, o Padre Leonel de Caldas, secretário desta inquirição, que o escrevi. O vigário, o padre Leonel de Caldas, Reitor José Pereira de Souto Maior (PEREIRA FILHO, 2009, fl. 7).

O longo processo de inquirição das testemunhas foi dividido em duas partes.

Na primeira parte foram ouvidas dez testemunhas da freguesia de São Tiago de Infesta, concelho de Coura: Bento Fernandes, lavrador e morador no lugar da Tomada; Manuel Martins, viúvo, lavrador e morador do lugar da Cruz, de cinquenta e cinco anos; Manuel Fernandes, lavrador e morador no lugar da Cruz, de sessenta anos; João Fernandes, viúvo, lavrador e morador no lugar da Rapadoura, de cinquenta e quatro anos; Francisco Álvares, lavrador e morador no lugar de Jancide, de cinquenta anos, pouco mais ou menos; João Fernandes, lavrador e morador no lugar de Jancide, de sessenta e cinco anos, pouco mais ou menos; Antônio Rodrigues, lavrador e morador no lugar Jancide, de trinta e três anos; João Fernandes, lavrador e morador no lugar das Barreiras, de cinquenta e cinco anos; Manuel Gonçalves, lavrador e morador no lugar de Jancide, de sessenta anos, pouco mais ou menos, e, aos costumes, disse nada e Bento Filgueira, lavrador e morador do lugar de Jancide, de trinta e seis anos, pouco mais ou menos. 
$\mathrm{Na}$ segunda parte foram ouvidas mais dez testemunhas da freguesia de Santa Maria de Cunha, concelho de Coura: João Pereira Barboza Soares, Cavaleiro do Hábito de Cristo e familiar do Santo Ofício, morador na sua quinta de Lizouros, de trinta e três anos; Manuel de Souza Caldas, homem nobre e morador na sua quinta da Porta da Igreja, de trinta e oito anos; Paulo Fernandes, lavrador e morador no lugar do Outeiro, de sessenta anos; Antônio Mendes, lavrador e morador no lugar do Outeiro, de trinta e oito anos; Domingos Vaz, lavrador e morador no lugar do Paço, de cinquenta e sete anos; Francisco Rodrigues, lavrador e morador no lugar de Cazelos, de quarenta e cinco anos; Simão da Cunha, lavrador e morador no lugar do Pedregal, de quarenta e cinco anos; João Rodrigues, lavrador e morador no lugar do Pedregal, de sessenta e cinco anos; Miguel da Cunha, lavrador e morador no lugar de Tozende, de cinquenta anos e Manuel da Cunha, lavrador e morador no lugar do Outeiro, de cinquenta e dois anos, pouco mais ou menos.

Não houve testemunha entre as vinte escutadas que denunciasse tivesse o habilitando Pascoal da Cunha qualquer evidência de impureza de sangue que o vinculasse ou os seus parentes aos defeitos da cor ou à relaxação dos costumes. Isso permitiu ao habilitando sua ordenação sacerdotal, como ficou concluído a oito de maio de 1713:

Vistas destes autos, em que se mostra ser o justificante, Paschoal da Cunha,
filho legítimo de Joseph da Cunha e de Maria da Cunha, da freguesia de São
Tiago de Infesta; neto pela parte paterna de Francisco da Cunha, da freguesia
de Santa Maria de Cunha, e de Joanna Francisca, da dita freguesia de Infesta;
e pela materna de João Fernandes da Cunha, da dita freguesia de Cunha, e de
Anna Rodrigues da dita freguesia de Infesta; em o mais, que dos autos consta.
Julgo ser o dito justificante, Paschoal da Cunha, legítimo e inteiro cristão
velho, sem nada de alguma nação infecta em seu sangue; e o habilito quanto
à pureza de seu sangue para todas as honras e dignidades eclesiásticas, que de
direito lhe possam competir. Pague os autos. E, passe sentença. Braga, 10 de
julho de 1713. Doutor Silvestre de Pinna e Pascal [?] Passe sentença
(PEREIRA FILHO, 2009, fl. 26).

A inquirição de genere do habilitando Pascoal da Cunha, posteriormente ordenado padre, demonstra os critérios para a aceitação na carreira sacerdotal, marcada profundamente pela mentalidade posterior do Concílio de Trento, especialmente presente na reforma católica e na sua contrarreforma. Para que houvesse sacerdotes preparados para o exercício pastoral nas paróquias era preciso fundamentar sua vocação começando pela natureza de seu sangue, ou seja, a lição explícita é que através do sangue do qual a cor é uma evidência visual determinase a priori a personalidade do futuro padre. Assim, a natureza boa ou má do habilitando herdada de seus ancestrais era uma porta estreita pela qual o habilitando era obrigado a passar para exercer sua profissão sacerdotal. 
Sobre essa estigmatização da ancestralidade judaica/cristã-nova, negra/mulata, moura/mourisca (além da indígena e da cigana) herdada pelo sangue, tornado ou não infecto, degradado e revelador da pureza ou impureza física e corporal e por isso mesmo espiritual como um pecado original insuperável, seria necessário estender-nos em longa análise, o que sairia de nosso objetivo principal. Em relação à impureza do sangue, a doutrina do sangue infecto revela como conviviam os portugueses no seu cotidiano com as culturas e raças consideradas degradadas naturalmente.

Ora, a ideia parece carecer de uma visão mais ontológica, ou seja, mais fundamentada da necessidade de constituição da diferenciação entre as pessoas no ambiente convivencial de suas culturas: se Deus é o criador da Terra e do cosmo, depreende-se que ele abençoou ou não as suas criaturas; por isso, aos abençoados revelou Deus na physis - natureza em grego - de cada um a sua marca criadora, o seu destino futuro, a sua vocação para os trabalhos manuais ou nobiliárquicos; a tentativa, contudo, parece ambígua, quando verifica-se que o mito fundador do cristianismo - o paraíso perdido de Adão e Eva - é uma cosmologia judaica apropriada pelo cristianismo e uma leitura simplista da condenação da tribo de Caim. No fundo, então, a discriminação do sangue e sua estigmatização sociocultural teria origem divina, pois o próprio Deus teria selado suas criaturas com sua marca de nascimento. Contudo, o "mito da pureza de sangue" (CARNEIRO, 2005, p. 55-58) é uma complexa doutrina dogmática e universal, carente de fundamentação científica, baseada exclusivamente em critérios ditos religiosos que são transformados como fundadores de uma prática social que parece explicar a xenofobia portuguesa ou se quisermos ser menos complacentes, o racismo incipiente, que no século XIX se impôs como governamentalidade das elites nacionais. Coloca-se em Deus, no mito primitivo e fundador não problematizado a origem do estigma da impureza de sangue que carrega desde o início a base ontológica para o racismo estrutural.

O padre Pascoal da Cunha Pereira não tinha sangue impuro, nem infecto, comprovou que seus ancestrais também não possuíam qualquer vestígio de degradação física ou natural, que pudesse obstar às suas funções dos cultos divinos. Ele passou pela porta estreita da inquirição de genere, vitce e moribus, mostrando aos seus investigadores que era um sangue puro, sem mácula, de vida exemplar e de bons costumes.

\section{Considerações finais}

As Constituições Primeiras do Arcebispado da Bahia de 1707 ordenaram e disciplinaram a malha eclesiástica nas minas do Serro do Frio em grande parte do século XVIII, 
principalmente no período do Antigo Regime português (1702-1750). A modelagem dessa extensa malha eclesiástica fundamentou-se na sombra tridentina, na reforma católica e na contrarreforma, com importantes aspectos da colonização mineira, sobretudo a presença da escravidão africana, perpetuada como aversão ao sangue infecto nos processos de averiguação de mulatismo dos habilitandos ao sacerdócio para o fornecimento de "curas d'alma" para as paróquias/freguesias e seus termos.

Em torno do Regimento dos Superintendes de 1702 e das Constituições Primeiras de 1707 foi realizado o processo de colonização das minas serranas. Pode-se afirmar de maneira conclusiva que as duas regulações foram fundamentais para a organização da malha populacional e eclesiástica que se formou nas minas gerais nos primeiros anos do século XVIII, em torno do complexo sistema do padroado real, em que a figura dos bandeirantes e dos primeiros oficiais do Senado da Câmara se misturavam com o poder e a autoridade com os primeiros padres, párocos e vigários. Contudo, foi em torno dos vigários que se conformaram as principais relações sociais serranas, em especial, em torno do adro da igreja matriz e de sua dinâmica litúrgica de festas e ofícios divinos, pois o padre recebia paróquia e nela permanecia durante longos anos, enquanto que os oficiais do Senado da Câmara eram eleitos anualmente.

Por fim, é indissociável a regulamentação oficial fosse da Igreja, fosse da Coroa portuguesa, da criação da malha ou rede de localidades que se constituíram no território das minas gerais nos primeiros anos do século XVIII. O padre estava em todas elas, ordenando os ofícios divinos, aplicando sacramentos, organizando a vida comunitária em torno de batizados e casamentos. Dessa forma, fica evidente que o sistema do padroado real funcionou desde os primeiros anos do território mineiro no ultimo quartel do século XVII e avançou de maneira uniforme até 1889 , com a proclamação da república. Entre a cruz e a coroa se fez a colonização brasileira nas minas gerais.

\section{Referências bibliográficas}

BIBLIOTECA NACIONAL. Documentos Históricos. Correspondência dos Governadores Gerais 1704-1714. V. XL. Carta para Antônio Soares Ferreira guarda-mor das Minas do Serro do Frio, sobre vários particulares tocantes às mesmas minas. Rio de Janeiro: Typ. Baptista de Souza, p. 352-360.

BOSCHI, Caio César. Em Minas, os negros e seus compromissos. In: MARTINS FILHO, Amílcar (Org.). Compromissos de irmandades mineiras do século XVIII. Belo Horizonte: Claro Enigma/Instituto Cultural Amílcar Martins, 2007, p. 277-293.

BOXER, Charles Ralph. A igreja e a expansão ibérica: 1440-1770. Lisboa: Edições 70, 2013. CARNEIRO, Maria Luiza Tucci. Preconceito racial em Portugal e Brasil Colônia. Os cristãos-novos e o mito da pureza de sangue. 3.ed. rev. amp. São Paulo: Perspectiva, 2005. 
CASIMIRO, Ana Palmira Bittencourt Santos. Constituições Primeiras do Arcebispado da Bahia: educação, lei, ordem e justiça no Brasil colonial. Disponível em: <http://www.histedbr.fe.unicamp.br/navegando/artigos_pdf/Ana_Palmira_Casimiro1_artigo.p df>. Acesso em: 20 jul. 2020.

COELHO, José João Teixeira. Instrução para o governo da Capitania de Minas Gerais. Belo Horizonte: Fundação João Pinheiro, 1994.

COSTA, Joaquim Ribeiro. Conceição do Mato Dentro, fonte de saudade. Belo Horizonte: Itatiaia, 1975.

FEITLER, Bruno; SOUZA, Evergton Sales; JANCSÓ, Istvan; PUNTONI, Pedro (Orgs.). Estudo introdutório. In: VIDE, Sebastião Monteiro da. Constituições Primeiras do Arcebispado da Bahia. São Paulo: Edusp, 2010.

FOUCAULT, Michel. Microfísica do poder. 6.ed. Rio de Janeiro/São Paulo, Paz e Terra, 2017.

MESQUITA, Sônia Nunes; SEABRA, Maria da Glória. Paróquia do Serro. História de fé. Serro: Edição das Autoras, 2013.

PEREIRA FILHO, Jorge da Cunha. Inquirição “de genere" de Paschoal da Cunha Pereira. Rio de Janeiro, Edição do Autor, 2009.

PINTO, Luiz Antônio. Memórias municipaes. Revista do Arquivo Público Mineiro, Belo Horizonte/MG, n. VII, p. 939-962, 1902.

SANTOS, Patrícia Ferreira dos. O Tribunal Eclesiástico à época de dom frei Manuel da Cruz: a afirmação da jurisdição episcopal. In: Travessias inquisitoriais das Minas Gerais aos cárceres do Santo Ofício: diálogos e trânsitos religiosos no império luso-brasileiro (sécs. XVIXVIII. FURTADO, Júnia Ferreira; RESENDE, Maria Leônia Chaves de. Belo Horizonte: Fino Traço Editora, 2013, p. 47-77.

SILVA, Dario Augusto Ferreira da. Memória sobre o Serro antigo. Serro: Typographia Serrana, 1928.

VAINFAS, Ronaldo. Trópico dos pecados. Moral, sexualidade e Inquisição no Brasil. Rio de Janeiro: Nova Fronteira, 1997.

VIDE, Sebastião Monteiro da. Constituições Primeiras do Arcebispado da Bahia. São Paulo: Edusp, 2010 [1707].

VILLALTA, Luiz Carlos. Introdução. In: RESENDE, Maria Efigênia Lage de; VILLALTA, Luiz Carlos (Orgs.). História de Minas Gerais. As minas setecentistas 2. Belo Horizonte: Autêntica; Companhia do Tempo, 2007a, p. 19-24.

VILLALTA, Luiz Carlos. A igreja, a sociedade e o clero. In: RESENDE, Maria Efigênia Lage de; VILlALTA, Luiz Carlos (Orgs.). História de Minas Gerais. As minas setecentistas 2. Belo Horizonte: Autêntica; Companhia do Tempo, 2007b, p. 25-57. 